\title{
The impact of national diabetic retinopathy screening on ophthalmology: the need for urgent planning
}

S Harding ${ }^{1}$, L Garvican² and J Talbot ${ }^{3}$

Eye (2005) 19, 1009-1011. doi:10.1038/sj.eye.6701751 published online 29 October 2004

Keywords: diabetic retinopathy; screening; hospital eye device

\section{Introduction}

With the introduction of the National Service Framework (NSF) for diabetes ${ }^{1,2}$ comes a requirement to introduce systematic screening for diabetic retinopathy. A target has been set of $80 \%$ coverage by 2006 rising to $100 \%$ by 2007 . In order to meet these requirements, programmes of retinopathy screening in the community will be introduced and existing programmes expanded. Quality assurance is the key driver for all aspects of the screening programme. A grading classification for England and Wales has been published $^{3}$ and a minimum data set for regional and national monitoring developed. ${ }^{4}$ Similar developments are underway in Scotland. ${ }^{5}$

Current practice for patients who screen positive, or who are picked up opportunistically, comprises follow-up within the Hospital Eye Service (HES) without any data collection or audit trail. As part of the new systematic approach, there will be a requirement to collect data from these patients as part of the National Minimum Data Set fed into local, regional and national quality assurance monitoring. This has a number of important implications for ophthalmologists and for the future organisation of ophthalmology services in the UK.

\section{Quality standards in National Service Framework for diabetes}

A series of 16 quality standards has been developed by the national programme team for use in England, Wales, and Northern Ireland and are in the public domain. ${ }^{4}$ A set of Clinical Standards has recently been published for use in Scotland, ${ }^{6}$ with similar implications for those involved in the programme there. The method of standard setting has been developed from that used in well-established screening programmes for breast and cervical cancer and comprise a 'minimum' acceptable standard below which no service should fall and an 'achievable' standard which is reasonable to expect every service to achieve. These standards will be measured for each programme through a three-tier process of local, regional, and national monitoring. The standards that are particularly relevant to the future development of the HES are outlined in Table 1.

Standard 1 requires the collection of visual acuity data not only on all patients with diabetes in the screening programme but also those being followed within the HES. The impact of this is that accurate best-corrected visual acuity measurement by trained staff using $\log$ MAR acuity charts will be required for all patients attending the HES with diabetes.

In order to meet standard 4, coverage will need to be measured against local and regional diabetes disease registers, which in turn will need links to the HES, posing a challenge to IT capabilities. As part of the National Screening Committee's implementation programme data collection exercise, software is required to allow concurrent electronic data entry. A list of approved suppliers of software to meet the national specification has been agreed. To ensure full data entry, software installation will be implemented within each eye department with training in its use by all staff assessing patients. Where this is not possible alternative arrangements will be required.
${ }^{1}$ St. Paul's Eye Unit, Royal Liverpool University Hospital,

Liverpool, UK

${ }^{2}$ National Quality Assurance Lead,

Diabetic Retinopathy, Screening Programme and Public Health Director, Sussex Cancer Network, UK

${ }^{3}$ Royal Hallamshire Hospital, Sheffield and Royal College of Ophthalmologists, UK

Correspondence: S Harding, St. Paul's Eye Unit, Royal Liverpool University Hospital,

Prescot Street, Liverpool L7 8XP, UK, Tel: + 44151706 4291; Fax: +44 1517065905 . E-mail: simonpharding@ aol.com

Received: 7 June 2004 Accepted: 7 September 2004

Published online: 29 October 2004 
Table 1 National quality standards for diabetic retinopathy screening relevant to hospital eye service

\begin{tabular}{|c|c|c|c|}
\hline Standard & Criterion & Minimum standard & Achievable standard \\
\hline 1 & $\begin{array}{l}\text { To reduce new blindness due to } \\
\text { diabetic retinopathy }\end{array}$ & $10 \%$ reduction within 5 years & $40 \%$ reduction within 5 years \\
\hline \multirow[t]{2}{*}{4} & \multirow{2}{*}{$\begin{array}{l}\text { To maximise the number of invited } \\
\text { persons accepting the screening test }\end{array}$} & Initial screen $-70 \%$, & Initial screen-90\% \\
\hline & & Repeat screen $-80 \%$ & Repeat screen-95\% \\
\hline 10 & $\begin{array}{l}\text { To ensure timely treatment of those } \\
\text { listed by ophthalmologist }\end{array}$ & $\begin{array}{l}\text { Time between listing and first laser in } \\
\text { a course: PDR - } 90 \% \text { within } 2 \text { weeks; } \\
\text { maculopathy - } 70 \% \text { within } \\
10 \text { weeks }\end{array}$ & $\begin{array}{l}\text { Time between listing and first laser in } \\
\text { a course: PDR - 95\% within } 2 \text { weeks; } \\
\text { maculopathy - 95\% within } 10 \text { weeks }\end{array}$ \\
\hline 11 & $\begin{array}{l}\text { To minimise overall delay between } \\
\text { screening event and first laser in a } \\
\text { course }\end{array}$ & $\begin{array}{l}\text { PDR }-70 \% \text { within } 4 \text { weeks; } \\
\text { maculopathy-70\% within } 15 \text { weeks }\end{array}$ & $\begin{array}{l}\text { PDR-95\% within } 4 \text { weeks; } \\
\text { maculopathy-95\% within } 15 \text { weeks }\end{array}$ \\
\hline 13 & To follow-up screen positive patients & $\begin{array}{l}\text { Did not attend/cancellation rate for } \\
\text { ophthalmology clinic: PDR }-<10 \% \\
\text { within } 1 \text { month; } \\
\text { maculopathy-<10\% within } \\
6 \text { months }\end{array}$ & $\begin{array}{l}\text { Did not attend/cancellation rate for } \\
\text { ophthalmology clinic: PDR }-<5 \% \\
\text { within } 1 \text { month; } \\
\text { maculopathy-<5\% within } \\
6 \text { months }\end{array}$ \\
\hline 15 & To ensure timely rescreening & $\begin{array}{l}70 \% \text { within } 1 \text { month of } 1 \text {-year } \\
\text { interval }\end{array}$ & $\begin{array}{l}95 \% \text { within } 1 \text { month of } 1 \text {-year } \\
\text { interval }\end{array}$ \\
\hline
\end{tabular}

Standards 10 and 11 are linked and translate into a requirement for the HES to maintain a minimal or no waiting list.

With the pressure on recent new patient waiting lists there has been a tendency for follow-up patients to have their routine appointments rescheduled. This, together with the introduction of partial booking systems, has resulted in the inevitable loss to follow-up of significant numbers of patients and accompanying press coverage. This will not be acceptable for patients with diabetes if the requirement to meet standards 13 and 15 is to be met.

\section{What we need to plan for}

Diabetic patients attending the HES fall into three categories:

1. Those attending for treatment and follow-up of diabetic retinopathy within medical retina clinics or within general ophthalmology services.

2. Those who are attending for treatment of other eye conditions.

3. Patients who require slit-lamp biomicroscopy as a result of not being able to undergo photographic screening (media opacity, poor mydriasis, poor cooperation) in order to complete their screening episode. This service should be overseen by the ophthalmologist and subject to quality assurance, although optometrists may perform the biomicroscopy.

Different solutions are required for each of these patient groups and should be tailored for local requirements. An ideal way forward for those attending for treatment or follow-up is to establish a dedicated diabetic retinopathy clinic, in which the necessary software and clerical support is available, with patients only being seen by medical and nursing staff trained in the accurate collection and entry of data.

For those patients attending general ophthalmology services for treatment of other eye disease there remains a requirement to ensure that systematic retinal screening takes place annually.

Patients in whom photographic screening is not feasible but for whom screening can be undertaken successfully by biomicroscopy will also require systematic screening. This would ideally be performed in the dedicated biomicroscopy clinics but if this is not possible then a paper-based tracking system to run within a general service will be required with careful attention to the associated administration.

\section{Conclusions}

Ophthalmologists face a series of challenges in the implementation of the NSC screening programme for sight-threatening diabetic retinopathy. The most pressing is to link with a local diabetologist to establish a project management team to include a local IT lead, trust management input and key stakeholders in Primary Care Trusts/Health Authorities. These challenges are similar to those being faced in the introduction of photodynamic therapy for choroidal neovascularisation and, in many centres, implementation is likely to fall on the same group of clinicians.

If the required coverage targets are to be achieved by 2006 and 2007, action plans and business cases must be 
agreed in the near future if there is to be realistic hope of meeting the needs of screening for our patients in a timely fashion.

\section{References}

1 Department of Health. National Service Framework for Diabetes The Standards. Department of Health, London, December 2001.

2 Department of Health. National Service Framework for Diabetes. Delivery Strategy. Department of Health, London, 2003.
3 Harding SP, Greenwood RM, Aldington A, Gibson JM, Owens DR, Taylor R et al. Grading and disease management in national screening for diabetic retinopathy in England and Wales. Diabet Med 2003; 20: 965-971.

4 UK National Screening Committee. Essential Elements in Developing a Diabetic Retinopathy Screening Programme. Workbook 2. February 2004. www.nscretinopathy.org.uk

5 Leese GP, Morris AD, Olsen J. A national retinal screening programme for diabetes in Scotland. Diabet Med 2003; 20: 962-964.

6 NHS Quality Improvement Scotland. Clinical Standards for Diabetic Retinopathy Screening. NHS Quality Improvement Scotland, March 2004. 